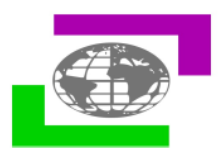

\title{
MEDICAL ETHICS: AYURVEDIC VIEW POINT IN PURVIEW OF CHARAK SAMHITA
}

\section{Dr Nidhi Sharma}

*PhD. Scholar, Dept of Samhita and Maulik Siddhanta, National Institute of Ayurveda, Jaipur

Article Info: Received 25 October 2018; Accepted 25 December. 2018

Cite this article as: Sharma, D. N. (2019). MEDICAL ETHICS: AYURVEDIC VIEW POINT IN PURVIEW OF CHARAK SAMHITA. Journal of Biomedical and Pharmaceutical Research, 7(6).

DOI: https://doi.org/10.32553/jbpr.v7i6.568

Address for Correspondence: Dr Nidhi Sharma, PhD. Scholar, Dept of Samhita and Maulik Siddhanta, National Institute of Ayurveda , Jaipur

Conflict of interest statement: No conflict of interest

\section{ABSTRACT:}

Ethics are the methods, policies, perspectives which decide a set of guidelines to act in a particular situation and for analyzing complex problem courses. The medical profession is governed by legislation and by code of ethics and etiquette. The ethical code in medicine has found their place from the very beginning. Ayurveda is the most ancient medical science. Charak Samhita is the one of the ancient authentic treatise of Ayurveda medicine. The code of ethics has been described on various places in the aforesaid text. The significance of ethical codes have increases manifold with the advent of time considering the shift of focus from serving mankind to financial benefits. The present paper deals with the review of medical ethics in Charak Samhita and analysis of their contemporary relevance.

Key words: Ayurveda, Ethics, Charak Samhita

\section{INTRODUCTION}

Ethics refers to the principles of conduct that govern the behavior of individuals which includes moral duties, obligations and responsibilities towards the concerned faculty. Ethics deals with distinction between right and wrong with the moral consequences of the actions. The medical profession is governed by legislation and by code of ethics and etiquette. Medical ethics is a voluntarily self-imposed code of conduct by the medical profession. The broad principles of medical ethics are formulated by National and State Medical Councils and the World Medical Association.
Enforcement of the code is done by the Medical Councils.

Code of ethics has a great deal in medical profession considering its intensity of impact on human life. Ayurveda is the most ancient medical science. It has got its origin from the Vedas, the most ancient scriptures. Vedas have also spoken about the ethics in chikitsa. Ayurveda has given the most primitive and organized glimpse about medical ethics especially in Charak Samhita. Charak Samhita is one of the ancient and prime treatises of Ayurveda system of medicine. It has enlightened the pathways to achieve excellence of every aspect of health. Besides 
dealing with diseases and their treatment, it has also mentioned certain ethics which deals with every sphere of human conducts to ensure quality life of individuals. The ethical conducts of Charak Samhita are the reflection of cultural belief, norms and values of the society of the particular era of its development. The ethical codes of Charak Samhita remains viable even in the face of contemporary deconstructionist trend in moral philosophy, in the profession and in the society owing to their scientific basis.

Charak Samhita is full of ethics regarding almost every aspect of life. The present paper deals with review of code of ethics depicted in Ayurvedic text Charak Samhita in relevance to medical profession and a critical analysis of their contemporary significance.

\section{Review of subject:}

Code of ethics has been given a great importance in ayurvdics classics. The major classics of Ayurveda are full of references of ethics. It is the Charak Samhita where the ethical codes were clearly defined in organized manner for the first time. The ethical codes of Caraka Samhita remains viable even in the face of contemporary deconstructionist trend in moral philosophy, in the profession and in the society owing to their scientific basis. The ethics in relation to chikitsa are as follows:

\section{Ethics for Physician:}

Physician is the most important pillar among the four pillar of treatment. The success of the treatment largely depends on the physician as he plans and carry out whole treatment procedure. A fair set of ethical codes have been cited in text right from the admission in medical program to the practice of medicine. Here, only ethics regarding medical practice are discussed which are as follows:

- Physician should be careful towards the selection of patient to be treated because the success of treatment depends a lot on the attitude of patient. Physician should not treat the patients who are fake in behavior, wicked or are of miserable conducts and behavior or who have not been absolved of the allegation against them or who are going to succumb to death.[1]

- Physician should not consider the treatment of patients who are despised by the king or noble persons and who despise the king and the noble person.

- Women should only be treated in the presence of their husband or guardian.[2]

- Physician should not accept anything given by women without the permission of her husband or guardian.

- Physician should enter the residence of the patient accompanied by a person who knows the place and who on his part, has obtained permission to enter there.

- While entering in the house, physician should be well clad with his head bowed down. He should be having concentrated mind and should act thoughtfully.

- After having entered in the house, physician should be fully devoted to the wellness of the patient by all his senses, speech, mind and intellect.

- Patient's family customs should not be revealed outside.

- Patient trusts a physician more than any other person not even his family members. So the liabilities of physician are extreme for the patient. Physician should treat all his patients like his children. [3]

- Physician should not disclose bluntly the coming death of the patient to the patient himself or to his close family members in order to avoid shock to the patient and the relatives.

- Physician should never have any ill will for the patients.

- The physician should not do exhibition of his wisdom unnecessarily.[4]

- Physician should pursue medical profession just out of compassion for the living being not as a commodity for earning wealth. 


\section{Ethical Values for the patient:}

Patients have been regarded as one of the most important pillar for the treatment to be successful. So, in Ayurveda ethics for the patients are given fair importance. The ethics of patients are as follows

Patient

- undergoing treatment, should reciprocate the physician by helping him whether such reciprocation was assured in advance or not.[5]

- Should possess qualities like good memory, fearlessness etc.

- Should have full orientation of his condition.

- Should be full faith in physician and should follow his instruction with all his capacities.

- Should be strong mentally and should not easily succumb to death.

\section{Ethics for medical attendant:}

Medical attendants play very important rule in treatment. The ethics for the attendant are follows:

- He should be affectionate and caring to the patient.[6]

- He should not hesitate in doing anything during the treatment procedure of the patient.[7]

\section{Ethics for drug collection: [8]}

Drugs are the main tools of the treatment. Collection and uses of drugs is also regulated by set of ethical conducts like

- Drugs should be collected in white attire.

- Drug should be collected after performing auspicious rites in a spirit of compassion, facing towards the east or north.

- Prayer should be offeres to god, Ashwins, cows and brahmana before the collection of drugs.

- Fasting should be done before drug collection and person should be living pure life.
- Before giving drug to the patient some auspicious ceremonies should be done like worshipping deities etc.

\section{Ethics for symposium: [9]}

Symposiums promote power of application of knowledge and competition leading to enlightenment. Some ethical conducts regarding symposium are-

$>$ A physician should participate in discussion with another physician.

$>$ Friendly discussions should be carried out with learned persons and with confidence.

$>$ One should not be jealous or irritated while discussions.

> Proper examination should be done before entering into discussion.

\section{Discussion:}

Ethics are the norms for conducts that distinguish between acceptable and unacceptable behavior. Ethics are the methods, policies, perspectives which decide a set of guidelines to act in a particular situation and for analyzing complex problem courses. The ethical rules are informal than laws as it is a person's choice to act in specific circumstances.

In Charak Samhita, ethical values have been mentioned regarding the medical profession and also for general population embracing all the aspect of life. Considering Charak Samhita as a medical treatise, the significance of description of medical ethics is self explanatory. The ethics regarding other aspect of life are significant in achieving the prime goal of the text i.e. healthy, happy (sukhayu) and useful life (hitayu) because these ethical norms are meant to acquire the control over the senses and to prevent indulgence in wrong practices which in turn prevents the dent in dignity of this noble profession. Charak Samhita has a strong scientific abode. Every ethical principle mentioned in it has some factual, scientific or logical back up and so the relevance in contemporary scenario is quite 
significant. Ethical norms are so ubiquitous that these can be inaccurately regarded as common sense. But common sense develops with experience and intellectual growth of an individual. It can have ethical basis and is undisputable whereas ethics are considered to be the informal laws comes in existence according to the need of individual and society to develop a best framework for both but can be differently interpreted and are liable to be a topic of disagreement.

Ethical values described in Charak Samhita remains valuable even in the contemporary world. The codes of conducts mentioned in it are barely the religious and cultural belief but have strong clinical justification also. To be healthy and to remain healthy are two prime concern of human so that they can achieve the goals of life. These norms of ethics assist in attaining these goals of life by enlightening righteous path and by making individuals to indulge in practices beneficial for health and in turn attaining their aim of life. Acharya Charak has clearly mentioned that knowledge about the prescription of authoritative sages and assimilation of such instructions helps in prevention and treatment of diseases.

The prime aim of medical science is to provide treatment to the diseased. Saving lives is considered as the noblest work on earth. Physicians are treated as God in the society as they are the saviors. Dealing with lives demands great responsibilities and enormous faith. These responsibilities are given a shape of code of ethics and persons related to medical science must ensure that these codes are vigilantly taken care of. Patients surrender themselves completely to the physicians. These ethics are helpful in protecting the rights of patients and simultaneously set a protocol to be followed in certain trying circumstances. These codes also keep the dignity of this profession intact. Observance of the principle of conducts helps to acquire control of sense organs and thus physician is not tempted to involve in activities harmful to him in sooner or later course of time. The compliance of ethical conducts also prevents the impairment of intellect by removing confusion and enlightens it with knowledge and so it does not coax the person to indulge in abusive activities which may result in diseases. Thus a person with intact intellect, memory, patience and proper knowledge of place and time is able to keep the diseases at bay by eluding the factors causing it.

The ethical codes of ancient times and in modern era have same underlying ideology on the relation of doctor and patient and on behavior of doctors in society. In ancient times the medical profession was more inclined to the benefit of society rather than earning money. In today's era of professionalism ethical codes have even more significance to keep the things in check. The clause of confidentiality, informed consent, pratyakhyeya chikitsa (discussing the prognosis before the treatment especially in incurable diseases), and behavior conducts in society have important place in contemporary ethical codes. The code of ethics in modern times seems to the extension of the ancient ethical codes and have become more organized and elaborated to prevent the misuse of the profession and aimed to serving the mankind largely.

According to Ayurveda, definition of health embraces physical, mental, social and spiritual aspects. [10] Mental health is maintained by following the conducts which increases the satva guna which is critical for a medical professional. It clears their thoughts and helps to make them quick decisions. This can be achieved by abstaining from ill emotions like hatred, anger etc., not indulging in sinful activities like violence etc., by accompanying good persons, by not procrastinating works etc. Social health is defined as the friendly, generous and salutary attitude of society for that person and also if that person is contributing to society positively and vice versa or simply a person is said to be socially 
healthy if he and society benefits each other positively. Some conducts regarding society have also been mentioned which includes the protocol to behave in society and helps in living in harmony with it e.g. compliance of rules of the institution, helping others etc. It also earns the person mental health directly or indirectly. Spiritual conducts like worshiping ancestors, meditation, yagya etc. works for wellness of the spirit.

In Charak Samhita medical ethics have been widely described. These ethical conducts helps in clearing the dilemma of physician e.g. regarding behavior with the patient, at the home of patient, in incurable cases etc. Ethics for patient, attendant have also been cited which are also important for proper treatment.

\section{Conclusion:}

From the above discussion it can be concluded that ethical norms-

- Are the codes of conducts which are the result of the experiences of the previous generation and gradually gained the status of informal rules.

- Enlightens the ways of action in vivid situations.

- Have definite factual and clinical back up.

- Are immensely important in maintenance of health - physical, mental, social and spiritual by avoiding the three causative factors of diseases.

- Are important in achieving four goals of life (purusharthacațuștaya).

- Are worth for this life and life beyond.

\section{References:}

1. Agnivesh, Viman Sthan, $8^{\text {th }}$ Chapter, Charak Samhita, Ayurveda Depika
Commentry by Chakrapanidutta, Pt. yadavji Trikamji Acharya, Rastriya Sanskrit Samsthan, Reprint 2006

2. Agnivesh, Chikitsa Sthan, $1^{\text {st }}$ Chapter, Charak Samhita, Ayurveda Depika Commentry by Chakrapanidutta, Pt. yadavji Trikamji Acharya, Rastriya Sanskrit Samsthan, Reprint 2006

3. Agnivesh, Viman Sthan, $8^{\text {th }}$ Chapter, Charak Samhita, Ayurveda Depika Commentry by Chakrapanidutta, Pt. yadavji Trikamji Acharya, Rastriya Sanskrit Samsthan, Reprint 2006

4. Agnivesh, Chikitsa Sthan, $1^{\text {st }}$ Chapter, Charak Samhita, Ayurveda Depika Commentry by Chakrapanidutta, Pt. yadavji Trikamji Acharya, Rastriya Sanskrit Samsthan, Reprint 2006

5. Agnivesh, Sutra Sthan, $9^{\text {th }}$ Chapter, Charak Samhita, Ayurveda Depika Commentry by Chakrapanidutta, Pt. yadavji Trikamji Acharya, Rastriya Sanskrit Samsthan, Reprint 2006

6. Agnivesh, Sutra Sthan, $15^{\text {th }}$ Chapter, Charak Samhita, Ayurveda Depika Commentry by Chakrapanidutta, Pt. yadavji Trikamji Acharya, Rastriya Sanskrit Samsthan, Reprint 2006

7. Agnivesh, Viman Sthan, $8^{\text {th }}$ Chapter, Charak Samhita, Ayurveda Depika Commentry by Chakrapanidutta, Pt. yadavji Trikamji Acharya, Rastriya Sanskrit Samsthan, Reprint 2006

8. Sushruta, Sutra Sthan, $15^{\text {th }}$ chapter, Sushrut Samhita, Nibandhasamgraha commentary by Dalhana, Yadavji, Trikamji Acharya editor, Chaukhamba Orientalia, $6^{\text {th }}$ Edition, 1997 